\title{
PREVALENCE OF CONSANGUINEOUS MARRIAGES IN SOUTH SINAI, EGYPT
}

\author{
G. YAMAMAH*, E. ABDEL-RAOUF $\dagger$, A. TALAAT*, A. SAAD-HUSSEIN $\ddagger$, \\ H. HAMAMY§ AND N. A. MEGUID $\dagger$ \\ * Department of Pediatrics, National Research Centre (NRC), Egypt, $\dagger$ Department of \\ Research on Children with Special Needs (NRC), Egypt, $\dagger$ Departments of Environmental \\ and Occupational Medicine (NRC), Egypt and \$Department of Genetic Medicine and \\ Development, Geneva University Hospital, Switzerland
}

\begin{abstract}
Summary. A total of 3961 married couples from six major geographical areas representing the South Sinai governorates in Egypt were studied to assess the rate of consanguineous marriage. The population of six selected areas ( $\mathrm{St}$ Catherines, Nuweiba, Abu Rudeis, Ras Sudr, El Tor and Abu Zenima) were subdivided into Bedouin, urban and mixed populations. A questionnaire-based interview was conducted showing that the consanguinity rate in this region is $37.5 \%$, with the highest rate recorded in Abu Rudeis $(52.3 \%)$ and lowest rate in Nuweiba (24.1\%). Consanguinity was significantly higher among the Bedouin population compared with the urban population in Abu Rudeis, Ras Sudr, El Tor and Abu Zenima, while in St Catherines and Nuweiba there was no statistically significant difference. Among consanguineous couples, 5\%,60\% and 35\% were double first cousins, first cousins and second cousins respectively. The mean inbreeding coefficient $\alpha$ of the studied population was 0.01845 .
\end{abstract}

\section{Introduction}

The Sinai Peninsula lies in the north-eastern corner of Egypt surrounded by the Red Sea on the south and bordered by the Mediterranean Sea in the north. The Gulf of Aqaba lies to the east of South Sinai extending from Ras Mohammed in the south to Taba in the north. It is about $250 \mathrm{~km}$ in length (Fig. 1).

In Egypt, consanguineous marriages have been prevalent since the time of the Pharaohs, when inbreeding pedigrees were recorded. Studies on the frequency of parental consanguinity in the Egyptian population have given figures ranging from 20.9 to $32.8 \%$ (Stevenson et al., 1966; Hafez et al., 1983; Mohamed, 1995; Mokhtar \& Abdel-Fattah, 2001), except for Nubia in the south where consanguinity raes as high as $60-80 \%$ have been reported (Hussien, 1971; Badr, 1972). Consanguinity rates were found to be higher in rural than in urban settings (Hafez et al., 1983). The most common consanguineous marriages in Egypt occur between first cousins (50\%), followed by first cousins once removed $(15 \%)$, second cousins $(15 \%)$ and other more distant relations (Hafez et al., 


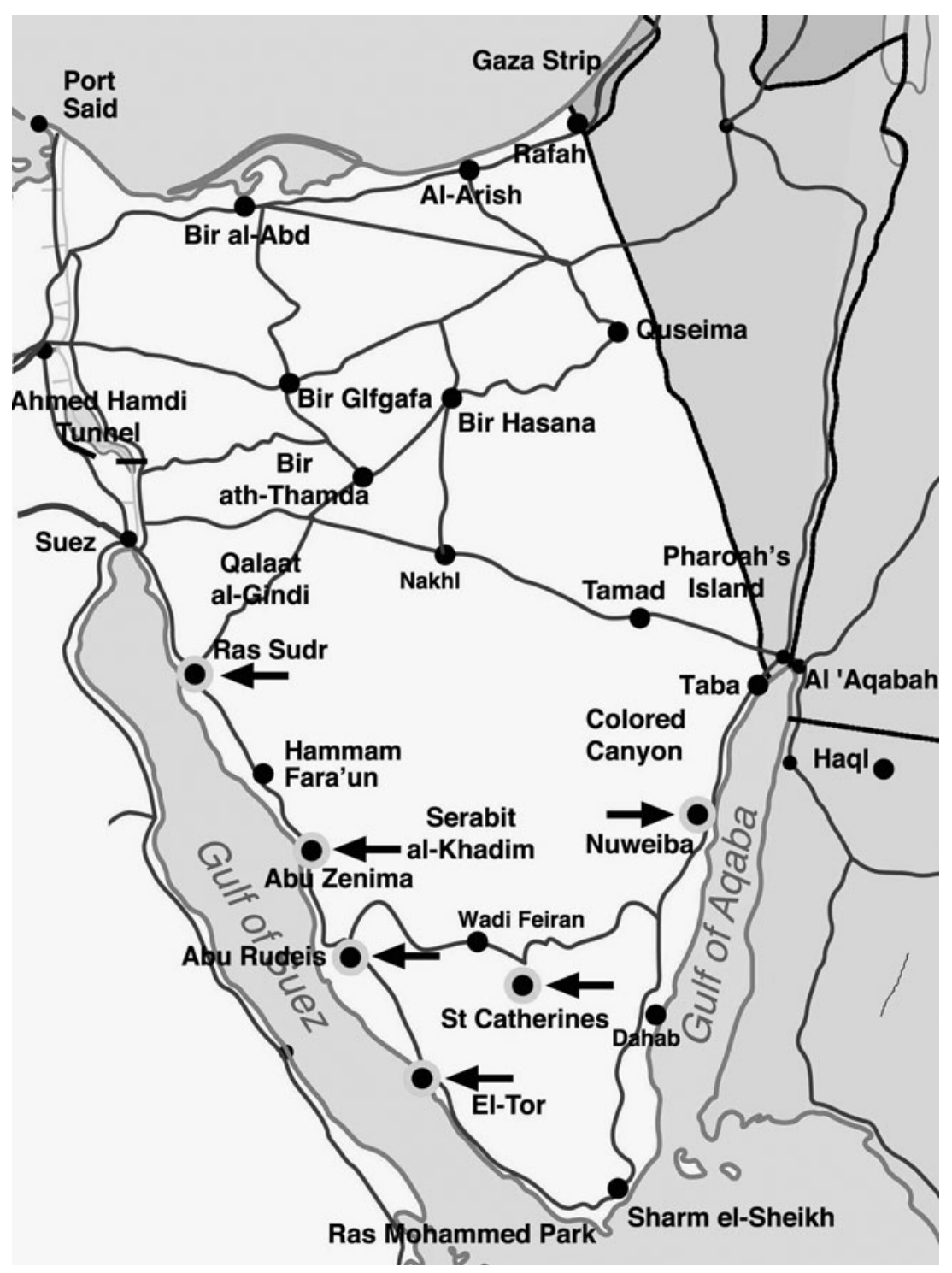

Fig. 1. Map of Egypt's Sinai Peninsula. The arrows point to the studied areas. URL: http://www.allsinai.info/bilder/maps/sinai04-b.jpg (no copyright indicated).

1983). The prevalence of consanguinity and rates of first cousin marriage vary widely within and between populations and communities, depending on ethnicity, religion, culture and geography. The consanguinity rates in most Arab countries range between 20 and 50\% (Tadmouri et al., 2009; Teebi, 2010). Consanguineous marriages are also practised among emigrant communities from highly consanguineous countries and regions such as Pakistan, Turkey, North Africa and Lebanon, now resident in Europe, North America and Australia (Hamamy et al., 2011). 
Consanguineous marriages are associated with an increased risk of congenital malformations and autosomal recessive diseases in offspring. With demographic and socioeconomic cofounders taken into consideration, some resultant increased postnatal mortality in the offspring of first cousin couples has also been described (Hamamy et al., 2011)

This is the first study assessing the rates of consanguinity among the population of South Sinai in Egypt.

\section{Methods}

A cross-sectional stratified survey was designed to study the prevalence and patterns of consanguinity among the population of South Sinai. Six major geographical localities out of the eight that are included in the Governorate of South Sinai were included in the study. These were St Catherines, Nuweiba, Abu Rudeis, Ras Sudr, E1 Tor and Abu Zenima. Each area was subdivided into Bedouin, urban and mixed populations.

The target population in South Sinai is 40,000. This study included 3961 interviewed couples and the sample size in each selected location was $\geq 385$, except for Abu Rudeis with 283 couples. Sample size was calculated according to the following formula:

$$
n=\frac{Z^{2} p(1-p)}{e^{2}}
$$

where $Z$ is the $Z$-value for the corresponding confidence level (1.96 for $95 \%$ confidence), $e$ is the margin of error $(0.05= \pm 5 \%)$ and $p$ is the estimated value for the proportion of a sample that have the condition of interest (Dawson-Saunders, 1994).

Field activities were carried out by trained interviewers on 3961 couples using a questionnaire covering the following indicators: residence, age, place of birth, educational level of husband and wife, age of marriage and any consanguineous relationship among the couple. Consanguineous marriages were classified as: first cousin, double first cousin, and second cousin marriages. Editing and coding were performed at the Department of Research on Children with Special Needs at the National Research Centre, Cairo. Field re-checks were done whenever needed.

The quantitative data were tabulated and analysed statistically using SPSS version 14.0. The data were expressed as number $(n)$ and percentage (\%). Pearson's Chisquared $\left(\chi^{2}\right)$ was used for analysis of the results. Significant difference was considered at $p$-value $\leq 0.05$. The mean inbreeding coefficient was calculated according to Emery (1976) as $\alpha=\sum P_{i} F_{i}$, where $F_{i}$ is the inbreeding coefficient of a certain category of consanguineous marriage and $P_{i}$ is the proportion of this category in the population.

\section{Results}

The consanguinity rate among 3961 couples in South Sinai in Egypt was 37.5\% (1484 couples). The highest rate of consanguinity was recorded in Abu Rudeis (52.3\%) while the lowest was recorded in Nuweiba (24.1\%) (Table 1). Furthermore, consanguinity was significantly higher in Bedouin compared with urban settings in Abu Rudeis, Ras Sudr, El Tor and Abu Zenima, but not in St Catherines and Nuweiba areas (Table 2). 
G. Yamamah et al.

Table 1. Consanguinity rates in different areas of South Sinai

\begin{tabular}{lcccccr}
\hline & \multicolumn{2}{c}{ Consanguineous } & & \multicolumn{2}{c}{ Non-consanguineous } & \\
\cline { 2 - 3 } \cline { 5 - 6 } Region & $n$ & $\%$ & & $n$ & $\%$ & Total \\
\hline St Catherines & 375 & 45.8 & & 444 & 54.2 & 819 \\
Nuweiba & 197 & 24.1 & & 622 & 75.9 & 819 \\
Abu Rudeis & 148 & 52.3 & & 135 & 47.7 & 283 \\
Ras Sudr & 377 & 44.0 & & 479 & 56.0 & 856 \\
El Tor & 258 & 33.2 & & 518 & 66.8 & 776 \\
Abu Zenima & 129 & 31.6 & & 279 & 68.4 & 408 \\
Total & 1484 & & & 2477 & & 3961 \\
\hline
\end{tabular}

$\chi^{2}=141.3 ; p<0.0001$.

Table 2. Consanguinity rates in Bedouin and urban settings in South Sinai

\begin{tabular}{|c|c|c|c|c|c|c|}
\hline \multirow[b]{2}{*}{ Region } & \multirow[b]{2}{*}{$\begin{array}{l}\text { Population } \\
\text { type }\end{array}$} & \multirow[b]{2}{*}{$\begin{array}{l}\text { Population } \\
\text { total }\end{array}$} & \multicolumn{2}{|c|}{ Consanguinity } & \multirow[b]{2}{*}{$\chi^{2}$} & \multirow[b]{2}{*}{$p$-value } \\
\hline & & & $\begin{array}{c}\text { No } \\
n(\%)\end{array}$ & $\begin{array}{c}\text { Yes } \\
n(\%)\end{array}$ & & \\
\hline $\begin{array}{l}\text { St Catherines } \\
(N=819)\end{array}$ & $\begin{array}{l}\text { Bedouin } \\
\text { Urban }\end{array}$ & $\begin{array}{l}716 \\
103\end{array}$ & $\begin{array}{r}380(53.1) \\
64(62.1)\end{array}$ & $\begin{array}{r}336(46.9) \\
39(37.9)\end{array}$ & 2.98 & $>0.05(\mathrm{~ns})$ \\
\hline $\begin{array}{l}\text { Nuweiba } \\
(N=819)\end{array}$ & $\begin{array}{l}\text { Bedouin } \\
\text { Urban } \\
\text { Mixed }\end{array}$ & $\begin{array}{r}379 \\
435 \\
5\end{array}$ & $\begin{array}{c}283(74.7) \\
334(76.8) \\
5(100)\end{array}$ & $\begin{aligned} 96 & (25.3) \\
101 & (23.2) \\
0 & (0)\end{aligned}$ & 2.09 & $>0.05(\mathrm{~ns})$ \\
\hline $\begin{array}{l}\text { Abu Rudeis } \\
(N=283)\end{array}$ & $\begin{array}{l}\text { Bedouin } \\
\text { Urban } \\
\text { Mixed }\end{array}$ & $\begin{array}{r}127 \\
116 \\
40\end{array}$ & $\begin{array}{l}46(36.2) \\
71(61.2) \\
18(45)\end{array}$ & $\begin{array}{l}81(63.8) \\
45(38.8) \\
22(55)\end{array}$ & 15.31 & $<0.0001$ \\
\hline $\begin{array}{l}\text { Ras Sudr } \\
(N=856)\end{array}$ & $\begin{array}{l}\text { Bedouin } \\
\text { Urban } \\
\text { Mixed }\end{array}$ & $\begin{array}{r}414 \\
429 \\
13\end{array}$ & $\begin{array}{r}181(43.7) \\
289(67.4) \\
9(69.2)\end{array}$ & $\begin{array}{r}233(56.3) \\
140(32.6) \\
4(30.8)\end{array}$ & 48.74 & $<0.0001$ \\
\hline $\begin{array}{l}\text { El Tor } \\
(N=776)\end{array}$ & $\begin{array}{l}\text { Bedouin } \\
\text { Urban } \\
\text { Mixed }\end{array}$ & $\begin{array}{r}330 \\
426 \\
20\end{array}$ & $\begin{array}{c}180(54.5) \\
327(76.8) \\
11(55)\end{array}$ & $\begin{array}{c}150(45.5) \\
99(23.2) \\
9(45)\end{array}$ & 42.63 & $<0.0001$ \\
\hline $\begin{array}{l}\text { Abu Zenima } \\
(N=408)\end{array}$ & $\begin{array}{l}\text { Bedouin } \\
\text { Urban } \\
\text { Mixed }\end{array}$ & $\begin{array}{r}128 \\
200 \\
80\end{array}$ & $\begin{array}{r}73(57.0) \\
149(74.5) \\
57(71.3)\end{array}$ & $\begin{array}{l}55(43.0) \\
51(25.5) \\
23(28.8)\end{array}$ & 11.39 & $<0.005$ \\
\hline Total & & & 2477 & 1484 & & \\
\hline
\end{tabular}

Among consanguineous couples, 60\% were first cousins, 35\% were second cousins and $5 \%$ double first cousins. First cousin and double first cousin marriages were more prevalent in Abu Rudeis, with a highly significant difference as compared with other areas. On the other hand second cousin marriages were significantly higher in St Catherines than in other areas (Table 3). 
Table 3. Categories of consanguineous marriages in different regions of South Sinai

$$
(N=1484)
$$

\begin{tabular}{lccc}
\hline & \multicolumn{3}{c}{ Degree of consanguinity } \\
\cline { 2 - 4 } Region & 1 st cousins & 2nd cousins & Double 1st cousins \\
St Catherines $(N=375)$ & $189(50.4)$ & $176(46.9)$ & $n(\%)$ \\
Nuweiba $(N=197)$ & $110(55.8)$ & $77(39.1)$ & $10(2.7)$ \\
Abu Rudeis $(N=148)$ & $102(68.9)$ & $26(17.6)$ & $10(5.1)$ \\
Ras Sudr $(N=377)$ & $250(66.3)$ & $119(31.6)$ & $20(13.5)$ \\
El Tor $(N=258)$ & $161(62.4)$ & $79(30.6)$ & $8(2.1)$ \\
Abu Zenima $(N=129)$ & $85(65.9)$ & $38(29.5)$ & $18(7.0)$ \\
Total & 897 & 515 & $6(4.7)$ \\
\hline
\end{tabular}

$\chi^{2}=79.56 ; p<0.0001$.

Table 4. Literacy and education levels of the South Sinai population $(N=3961)$

\begin{tabular}{lcc}
\hline \multicolumn{1}{c}{ Education level } & $\begin{array}{c}\text { Bedouin and mixed } \\
n(\%)\end{array}$ & $\begin{array}{c}\text { Urban } \\
n(\%)\end{array}$ \\
\hline Illiterate & $1419(63)$ & $102(6)$ \\
Can read and write & $450(20)$ & $137(8)$ \\
Primary schooling & $225(10)$ & $137(8)$ \\
Preparatory schooling & $113(5)$ & $205(12)$ \\
Secondary schooling & $45(2)$ & $547(32)$ \\
University or high institute & $0(0)$ & $581(34)$ \\
Total & 2252 & 1709 \\
\hline
\end{tabular}

The mean inbreeding coefficient of the screened population in South Sinai was 0.0184. In previous studies the average inbreeding coefficient in the Egyptian population was found to be 0.010-0.0117 (Hafez et al., 1983; Mohamed, 1995). These figures are considered high compared with most Western societies, where the average inbreeding coefficient is usually less than 0.001 (Bittles, 2011).

A very high rate of illiteracy was found to be prevalent among Bedouin $(63 \%)$ in comparison with the urban $(6 \%)$ populations. On the other hand, no single Bedouin student could be affiliated to a high institute or a university, while $34 \%$ of the urban ones enjoyed this level of higher education (Table 4).

\section{Discussion}

Consanguineous marriage reflects a social and cultural tradition that differs in incidence from area to area depending on the customs of the society as well as on the religion. In this study, the consanguinity rate among 3961 couples in South Sinai in Egypt was found to be $37.5 \%$, with the highest rate of $52.3 \%$ being recorded in the Abu Rudeis region. High rates of $52 \%$ in Saudi Arabia (al-Abdulkareem \& Ballal, 1998), 50.5\% 
in UAE (al-Gazali et al., 1997) and 51\% in Qatar (Sandridge et al., 2010) have been reported. This could reflect the closely similar socio-cultural heritage and a tribal affinity relationship. Socio-cultural factors such as maintenance of family structure, ease of marital arrangements, better relations with in-laws, and financial advantages relating to dowry seem to play a crucial role in the preference for consanguineous marriages in Arab populations as in other highly consanguineous populations (Bittles, 2008).

As in most Arab countries, the most common types of consanguineous marriage in South Sinai were those contracted among first cousins, at $22.6 \%$. Some neighbouring countries have shown higher rates for first cousin marriages, such as Saudi Arabia (33.6\%), Sudan (44.2\%), Jordan (32.8\%) and Palestinians in Gaza (31.6\%) (Tadmouri et al., 2009). In some of these countries, however, the rate is declining with time, such as in Jordan where first cousin marriages in recent generations have been reported to be $19 \%$ (Hamamy et al., 2005). A very similar figure for first cousin marriages has been reported for the UAE $(26.2 \%)$, although double first cousin marriages in UAE were higher than in Sinai (3.5\% vs. 1.8\%) (al-Gazali et al., 1997). This may reflect certain cultural differences among these populations since the total consanguinity rate was higher in UAE than in the studied population in Sinai (50.5\% vs 37.5\%) (al-Gazali et al., 1997).

The age of marriage in South Sinai is generally 20 years for men and 17 years for women, and by the time of menopause $(45+$ years $)$ Sinai Bedouin women have had on average 5.5 living children with overall fecundity of about 7 children (Leonard \& Crawford, 2002).

The ideal marriage is considered to be a paternal parallel first cousin (father's brother's daughter) marriage. If such a marriage is impossible, the next preferred marriage is to mother's brother's daughter. Father's brother's daughter is considered to be preferred in most Muslim communities in the Middle East. For example in Jordan, UAE and Yemen, 57\%, 64.4\% and 71.8\%, respectively, of all first cousin marriages are paternal parallel marriages (father's brother's daughter) (al-Gazali et al., 1997; Jurdi \& Saxena, 2003; Hamamy et al., 2005). In Sinai, a negative association was seen between husband and wife kinship and polygamy: namely, in first cousin marriages, the husband is less likely to acquire a second wife (Leonard \& Crawford, 2002).

Longstanding familiarity and sharing similar traditions and customs with relatives also contribute to the preference for consanguineous marriages (Mohamed, 1995). Contrary to common opinion, consanguinity is not only confined to Muslim communities. Many other religious groups, including the Lebanese, Jordanian and Palestinian Christian populations, also practise consanguineous marriage, although to a lesser extent than among co-resident Muslims (Khlat, 1988; Khoury \& Massad, 1992; Vardi-Saliternik et al., 2002). Despite the fact that rare recessively inherited diseases are more likely to be expressed in highly consanguineous populations (Teebi, 2010), low genetic literacy and lack of proper information are still widely prevalent among the public. A report from Alexandria (Mohamed, 1995) indicated that 30\% of the studied female cases lack the knowledge that consanguineous marriage might increase the risk of congenital disorders in offspring.

In this study, the consanguinity rate was found to be significantly higher in all Bedouin areas except for St Catherines and Nuweiba, reaching the highest peak in Abu Rudeis. Such results are expected since Bedouin society is somewhat isolated and family relations 
are stronger than in urban areas. The relative frequency of consanguineous marriages being more in Bedouin than urban areas could be attributed to the abundance of relatives of a given degree, the availability of consanguineous individuals in an appropriate geographical or social space, the availability of related individuals belonging to an age group, the social norms favouring some type of consanguineous unions, and factors depending on the social structure, on the education levels and on the culture of the Bedouin population. For example, a very high rate of illiteracy was found to be prevalent among Bedouin (63\%) in comparison with urban (6\%) populations (Table 4).

Similarly, studies in the Arab world have shown that consanguineous marriage is most prevalent in rural communities following more traditional lifestyles (Hafez et al., 1983; Zaoui \& Biemont, 2002). In general, the highest prevalence of consanguineous marriage is concentrated among families with the lowest standard of living (Assaf \& Khawaja, 2009) and where wives have a lower level of education (Jurdi \& Saxena, 2003). The rate of first cousin mating was highest in Bedouins $(37 \%)$ and Druze $(37 \%)$, who have the lowest educational levels, and lowest in highly educated Christian Arabs (14\%) and non-Bedouin Muslim Arabs in Israel (10\%) (Vardi-Saliternik et al., 2002).

Secular changes in consanguinity rates have been noticed in some Arab populations. In Jordan (Hamamy et al., 2005), Bahrain (Tadmouri, 2009) and among Palestinians (Assaf \& Khawaja, 2009; Jaber et al., 2000) the frequency of consanguineous marriage is decreasing. Several factors may play a role in decreasing the consanguinity rates in Arab countries, including increasing female education levels, declining fertility resulting in lower numbers of suitable relatives to marry, more mobility from Bedouin to urban settings, and the improving economic status of families. Further studies in South Sinai could assess such secular trends.

The peripheral nature of South Sinai due to its history of isolation and geographical location has kept its Bedouin nomads separated from the Egyptian modern state. The Sinai Bedouins are traced to pure Arabian ancestry. Bedouins of Sinai in general are known for their hospitality, generosity, respect for the rights of others, love for justice and freedom, consultation in public matters, caring and providing for camels, and pride in avoiding all contact with 'civilization' (Hobbs, 1989). The Bedouin social structure is segmentary, which means that small independent and closely related families can join to form larger organized and co-operative groups, which then form tribes. The tribes at the higher levels join other groups on the same level to form alliances.

In present day Sinai Peninsula, there are approximately 50,000 Bedouins divided into about fourteen tribes and sub-tribes. Throughout the South Sinai Peninsula are scattered ten tribes totalling about 10,500 individuals, as reported in 1976 (Leonard \& Crawford, 2002), and 20,000-24,000 as reported in 2003 (SEAM, 2004). Most of the tribes originated from the Arabian Peninsula, some came from North Africa and Egypt, and one tribe, the Gebeliya tribe, which showed differing frequencies of some genetic markers from the other tribes, might have originated from south-east Europe. A reappraisal of the historical and ethnic background of this tribe is recommended (Leonard \& Crawford, 2002).

In South Sinai, tribal territories and the Bedouin population are smaller than in the north, and they are collectively referred to as the Arabs of El Tor, formerly a major port and now South Sinai's regional capital. Of the population of Sharm El Sheikh, the centre of tourism in Sinai, only $15.5 \%$ of the population are reported to be Bedouin 
(Goodwin, 2006). Bedouin can no longer rely on fishing and grazing as a means of subsistence, as expansion of tourist resorts along the coast has displaced other land uses and denied Bedouin fishermen access to the sea. Instability in the region since 1948, with three wars in Sinai in 1956, 1967 and 1973, has delayed the integration of South Sinai with the rest of Egypt.

In conclusion, the consanguinity rates among the population of South Sinai are close to the consanguinity rates previously reported in Egypt, with some variations being noted among the different regions studied in this report and significantly higher rates among the rural Bedouins than in urban populations.

\section{Acknowledgments}

This document has been produced with the financial assistance of the EU. All authors declare that there is no conflict of interest.

\section{References}

al-Abdulkareem, A. A. \& Ballal, S. G. (1998) Consanguineous marriage in an urban area of Saudi Arabia: rates and adverse health effects on the offspring. Journal of Community Health 23, 75-83.

al-Gazali, L. I., Bener, A., Abdulrazzaq, Y. M., Micallef, R., al-Khayat, A. I. \& Gaber, T. (1997) Consanguineous marriages in the United Arab Emirates. Journal of Biosocial Science 29, 491497.

Assaf, S. \& Khawaja, M. (2009) Consanguinity trends and correlates in the Palestinian Territories. Journal of Biosocial Science 41, 107-124.

Badr, F. M. (1972) Genetic studies of Egyptian Nubian populations. I. Frequency and types of consanguineous marriages. Human Heredity 22, 387-398.

Bittles, A. (2011) The Global Prevalence of Consanguinity. URL: http://www.consang.net (accessed June 2011).

Bittles, A. H. (2008) A community genetics perspective on consanguineous marriage. Community Genetics 11, 324-330.

Dawson-Saunders, B. T. R. G. (1994) Basic and Clinical Biostatistics (2nd Edition). Prentice-Hall International Inc., Lange Medical Books.

Emery, A. E. H. (1976) Methodology in Medical Genetics. Churchill Livingstone, Edinburgh, p. 16.

Goodwin, H. (2006) Measuring and Reporting the Impact of Tourism on Poverty. School of Management, University of Surrey, UK. URL: http://haroldgoodwin.info/resources/measuring.pdf.

Hafez, M., El-Tahan, H., Awadalla, M., El-Khayat, H., Abdel-Gafar, A. \& Ghoneim, M. (1983) Consanguineous matings in the Egyptian population. Journal of Medical Genetics 20, 58-60.

Hamamy, H., Antonarakis, S. E., Cavalli-Sforza, L. L., Temtamy, S., Romeo, G., Ten Kate, L. P. et al. (2011) Consanguineous marriages, pearls and perils: Geneva International Consanguinity Workshop Report. Genetics and Medicine 13, 841-847.

Hamamy, H., Jamhawi, L., Al-Darawsheh, J. \& Ajlouni, K. (2005) Consanguineous marriages in Jordan: why is the rate changing with time? Clinical Genetics 67, 511-516.

Hobbs, J. J. (1989) Bedouin Life in the Egyptian Wilderness. University of Texas Press, Austin, TX.

Hussien, F. H. (1971) Endogamy in Egyptian Nubia. Journal of Biosocial Science 3, 251-257.

Jaber, L., Halpern, G. J. \& Shohat, T. (2000) Trends in the frequencies of consanguineous marriages in the Israeli Arab community. Clinical Genetics 58, 106-110. 
Jurdi, R. \& Saxena, P. C. (2003) The prevalence and correlates of consanguineous marriages in Yemen: similarities and contrasts with other Arab countries. Journal of Biosocial Science 35, $1-13$.

Khlat, M. (1988) Consanguineous marriages in Beirut: time trends, spatial distribution. Social Biology 35, 324-330.

Khoury, S. A. \& Massad, D. (1992) Consanguineous marriage in Jordan. American Journal of Medical Genetics 43, 769-775.

Leonard, W. \& Crawford, M. (2002) Human Biology of Pastoral Populations. Cambridge University Press, UK.

Mohamed, M. (1995) An epidemiological study on consanguineous marriage among urban population in Alexandria. Journal of the Egyptian Public Health Association 70(3-4), 293-305.

Mokhtar, M. M. \& Abdel-Fattah, M. M. (2001) Consanguinity and advanced maternal age as risk factors for reproductive losses in Alexandria, Egypt. European Journal of Epidemiology 17, 559-565.

Sandridge, A. L., Takeddin, J., Al-Kaabi, E. \& Frances, Y. (2010) Consanguinity in Qatar: knowledge, attitude and practice in a population born between 1946 and 1991. Journal of Biosocial Science 42, 59-82.

SEAM, P. (2004) South Sinai Environmental Action Plan: South Sinai Demographics and Population Projections. URL: http://st-katherine.net/downloads/Demographics\%20\&\%20Population.pdf.

Stevenson, A. C., Johnston, H. A., Stewart, M. I. \& Golding, D. R. (1966) Congenital malformations. A report of a study of series of consecutive births in 24 centres. Bulletin of the World Health Organization 34, S127.

Tadmouri, G. (2009) Genetic disorders in Arab Populations: a 2006 Update. In Tadmouri, G. O., Taleb, Al A. M. \& Al Khaja, N. (eds) Genetic Disorders in the Arab World. Bahrain, Dubai.

Tadmouri, G. O., Nair, P., Obeid, T., Al Ali, M. T., Al Khaja, N. \& Hamamy, H. A. (2009) Consanguinity and reproductive health among Arabs. Reproductive Health 6, 17.

Teebi, A. (2010) Genetic Disorders among Arab Populations (2nd Edition). Springer, Berlin, Heidelberg.

Vardi-Saliternik, R., Friedlander, Y. \& Cohen, T. (2002) Consanguinity in a population sample of Israeli Muslim Arabs, Christian Arabs and Druze. Annals of Human Biology 29, 422-431.

Zaoui, S. \& Biemont, C. (2002) [Frequency of consanguineous unions in the Tlemcen area (West Algeria)]. Sante 12, 289-295. 